\title{
How do basic secretagogues activate mast cells?
}

\author{
Roland Seifert
}

Received: 14 January 2015 / Accepted: 19 January 2015 /Published online: 1 February 2015

(C) Springer-Verlag Berlin Heidelberg 2015

Mast cells play a critical role in the pathogenesis of anaphylaxis (DeBruin et al. 2015). Upon activation, mast cells release a number of pro-inflammatory mediators that together induce bronchoconstriction, angioedema, particularly in the oral cavity and the larynx, and a drop in blood pressure. Mast cell activation is either induced via an allergen-IgE-dependent mechanism or an IgE-independent mechanism. The latter mechanism is also referred to as pseudo-allergy (Wang et al. 2011). A recent letter published in Nature (McNeil et al. 2014) rekindled the interest in the molecular mechanisms underlying pseudo-allergy.

Pseudo-allergic reactions can be induced by a number of clinically used drugs including non-depolarizing muscle relaxants, peptide drugs, quinolone antibiotics, and morphine, and certain insect venoms (Wang et al. 2011). The cationic-amphiphilic wasp venom mastoparan is considered as a prototypical mast cell activator (Mousli et al. 1990a). Another mast cell activator broadly employed in experimental pharmacology and immunology is "compound 48/80," a polymer produced by the condensation of N-methyl-p-methoxyphenethylamine and formaldehyde. Pseudo-allergic reactions upon exposure to drugs or wasp venoms can be life-threatening. The $\alpha$ - and $\beta$-adrenoceptor agonist adrenaline constitutes a life-saving symptomatic treatment for anaphylaxis (Fleming et al. 2015). However, it would be very desirable to prevent pseudo-allergic reactions in the first place. Therefore, it is important to understand the molecular mechanisms underlying pseudo-allergic reactions.

R. Seifert $(\bowtie)$

Hannover Medical School, Institute of Pharmacology,

Carl-Neuberg-Straße 1, 30625 Hannover, Germany

e-mail: seifert.roland@mh-hannover.de
A common structural property of pseudo-allergy-inducing compounds is that they are all basic and contain hydrophobic domains. Accordingly, the compounds are globally classified as cationic-amphiphilic drugs (CADs) or basic secretagogues. In the late 1980s to the mid-1990s, numerous research groups invested a lot of effort to delineate the molecular mechanism of action of CADs. Seminal studies were performed with rat mast cells (Mousli et al. 1989; Aridor et al. 1990; Bueb et al. 1990) due to the very limited availability of native human mast cells. In addition, as substitute for human mast cells, several studies were performed with human neutrophils and HL-60 leukemia cells, constituting well-established and wellunderstood myeloid model cell types (Perianin and Synderman 1989; Norgauer et al. 1992; Klinker et al. 1994). In aggregate, these studies suggested that CADs activate myeloid cells by a G-protein-coupled receptor (GPCR)-like but nonetheless GPCR-independent mechanism, involving, at least in part, pertussis toxin-sensitive $\mathrm{G}_{\mathrm{i}}$-proteins.

In 1988, Higashijima et al. reported that mastoparan is capable of activating purified $\mathrm{G}_{\mathrm{i}^{-}}$and $\mathrm{G}_{\mathrm{o}}$-proteins directly. Follow-up studies corroborated the concept and demonstrated that numerous CADs act in a similar manner as mastoparan (Higashijima et al. 1990; Mousli et al. 1990b; Hagelüken et al. 1995a; Breitweg-Lehmann et al. 2002). Elegant mechanistic studies identified the interaction sites of mastoparan on Gproteins and revealed that mastoparan acts as a GPCR mimetic to promote GDP dissociation from G-protein $\alpha$-subunits (Higashijima et al. 1990; Weingarten et al. 1990; Higashijima and Ross 1991; Tanaka et al. 1998). Overall, the CAD studies with purified G-proteins corroborated the conclusions of studies obtained with intact cells. No GPCR was required to explain myeloid cell activation by CADs.

Due to their physiochemical properties, mastoparan and related CADs can exert pleiotropic effects such as changes 
in membrane fluidity, increases in cell permeability, and activation of non-specific nucleotidases and nucleoside diphosphokinases (Denker et al. 1991; Klinker et al. 1994; de Azevedo et al. 2014). While a certain degree of G-protein and cell type specificity of the pharmacological effects of CADs could be obtained (Higashijima et al. 1990; Hagelüken et al. 1995b; Sukumar et al. 1997) and Gproteins were suggested to constitute pharmacological targets on their own right, the pleiotropic actions of CADs and negatively charged G-protein inhibitors were a serious concern (Freissmuth et al. 1999). For these reasons, very little research has been performed in the field since then.

McNeil et al. (2014) have now identified a mast cellspecific GPCR in mice, referred to as Mrgrb2, which is activated by CADs and mediates pro-inflammatory reactions such as histamine release from mast cells, airway constriction, and paw edema in vivo as shown by receptor knock-out studies. The authors also report that the human ortholog of this receptor, MRGRX2, is activated by CADs. Based on these data, McNeil et al. (2014) proposed that CADs mediate their pseudo-allergy-inducing effects via a mast cell-specific GPCR. Such a mechanism would open the door for the development of allergy-preventing antagonists, specifically in light of the fact that MRGRX2 is expressed only in mast cells but not peripheral white blood cells.

Thus, there are now two hypotheses of how CADs could activate mast cells, but which one is correct? In their paper, McNeil did not discuss the G-protein hypothesis of CAD action. In Extended Data Fig. 10 (panel b), the authors show that siRNA against MRGRX2 only partially reduces activation by CADs of cultured human LAD2 mast cells. This finding is compatible with the notion that both GPCR-dependent and GPCR-independent mechanisms are involved in the process. This assumption is supported by the fact that the inhibitory effect of the siRNA is stimulus dependent. For example, the effect of mastoparan is more resistant to inhibition than the effect of compound 48/80. McNeil et al. transfected HEK293 cells with Mrgrb2 or MRGRX2 and the pertussis toxininsensitive "universal" G-protein $\mathrm{G}_{15}$ (Offermanns and Simon 1995) to induce rises in intracellular calcium. For reconstitution of the canonically $\mathrm{G}_{\mathrm{i}}$-coupled histamine $\mathrm{H}_{4}$-receptor and the canonically $\mathrm{G}_{\mathrm{q}}$-coupled histamine $\mathrm{H}_{1}$-receptor in HEK cells in terms of calcium signaling, co-transfection with a universal adapter G-protein is not necessary (Beermann et al. 2014). However, it is possible that coupling of Mrgrb2 and MRGRX2 to the endogenous G-proteins in HEK cells is not efficient enough to elicit a calcium signal. McNeil did not discuss the possible physiological G-protein coupling of Mrgrb2 or MRGRX2. In addition, it was not explicitly reported by McNeil et al. (2014) whether CADs exhibited stimulatory effects in non-transfected HEK293 cells.

To further complicate the situation, CADs often shown complex concentration-response curves, e.g., with Hill coefficients $>>1$ (reflecting cooperative binding to the target protein), and curves can be biphasic (reflecting toxic and/or non-specific effects at higher concentrations) or do not reach saturation altogether (Higashijima et al. 1988, 1990; Klinker et al. 1994; Hagelüken et al. 1995a; Breitweg-Lehmann et al. 2002). The concentrations of mastoparan used by McNeil et al. (2014) to activate Mrgrb2 or MRGRX2 are in the same range as the concentrations typically used to activate Gproteins directly (Higashijima et al. 1990), rendering discrimination of the two targets based on ligand-selectivity impossible. From the paper of McNeil et al. (2014), it is not clear that all of the necessary control experiments with non-transfected cells, cells with just receptor, or G-protein alone and with complete concentration-response curves of CADs in control groups were performed to rule out receptor-independent Gprotein activation by CADs.

In conclusion, the field of mast cell activation by CADs, after long dormancy, has been recently revived, and an intriguing new mechanism of action has been proposed. However, it is too early to dismiss the compelling evidence accumulated by several groups a long time ago that CADs bypass GPCRs to induce mast cell activation. It is reasonable to assume that both GPCR-dependent and GPCR-independent mechanisms are involved in CAD-induced pseudo-allergy. For 2phenylhistamines, histamine $\mathrm{H}_{1}$-receptor-dependent and $\mathrm{H}_{1}$ receptor-independent G-protein-mediated effects have already been documented (Hagelüken et al. 1995b; Seifert et al. 1994, 2013). Understanding the mechanism of CAD action is not only of academic interest but also of therapeutic relevance because direct G-protein activation is expected to be less accessible to pharmacological intervention than GPCRmediated mechanisms.

\section{References}

Aridor M, Traub LM, Sagi-Eisenberg R (1990) Exocytosis in mast cells by basic secretagogues: evidence for direct activation of GTPbinding proteins. J Cell Biol 111:909-917

Beermann S, Vauth M, Hein R, Seifert R, Neumann D (2014) Distinct signalling pathways of murine $\mathrm{H}_{1}$ - and $\mathrm{H}_{4}$-receptors expressed at comparable levels in HEK293 cells. PLoS One 9:e107481

Breitweg-Lehmann E, Czupalla C, Storm R, Kudlacek O, Schunack W, Nürnberg B (2002) Activation and inhibition of $G$ proteins by lipoamines. Mol Pharmacol 61:628-636

Bueb JL, Mousli M, Bronner C, Rouot B, Landry Y (1990) Activation of $\mathrm{G}_{\mathrm{i}}$-like proteins, a receptor-independent effect of kinins in mast cells. Mol Pharmacol 38:816-822

De Azevedo RA, Figueiredo CR, Ferreira AK, Matsuo AL, Massaoka $\mathrm{MH}$, Girola N, Auada AV, Farias CF, Pasqualato KF, Rodrigues CP, Barbuto JA, Levy D, Bydlowski SP, da Sa-Junior PL, Travassos LR, Lebrun I (2014) Mastoparan induces apoptosis in B16F10-Nex2 melanoma cells via the intrinsic mitochondrial pathway and displays antitumor activity in vivo. Peptides (in press). 
DeBruin EJ, Gold M, Lo BC, Synder C, Cait A, Lasic N, Lopez M, McNagny KM, Hugher MR (2015) Mast cells in human health and disease. Methods Mol Biol 1220:93-119

Denker BM, Tempst P, Neer EJ (1991) Characterization of a mastoparanstimulated nucleotidase from bovine brain. Biochem J 278:1-5

Fleming JT, Clark S, Camargo CA Jr, Rudders SA (2015) Early treatment of food-induced anaphylaxis with epinephrine is associated with a lower risk of hospitalization. J Allergy Clin Immunol Pract 3:57-62

Freissmuth M, Waldhoer M, Bofill-Cardona E, Nanoff C (1999) G protein antagonists. Trends Pharmacol Sci 20:237-245

Hagelüken A, Nürnberg B, Harhammer R, Grünbaum L, Schunack W, Seifert R (1995a) The class III antiarrhythmic drug amiodarone directly activates pertussis toxin-sensitive $\mathrm{G}$ proteins. Mol Pharmacol 47:234-240

Hagelüken A, Grünbaum L, Klinker FJ, Nürnberg B, Harhammer R, Schultz G, Leschke C, Schunack W, Seifert R (1995b) Histamine receptor-dependent and/or -independent activation of guanine nucleotide-binding proteins by histamine and 2-substituted histamine derivatives in human leukemia (HL-60) and human erythroleukemia (HEL) cells. Biochem Pharmacol 49:901-914

Higashijima T, Ross EM (1991) Mapping of the mastoparan-binding site on $\mathrm{G}$ proteins. Cross-linking of $\left[{ }^{125} \mathrm{I}-\mathrm{Tyr} 3\right.$, Cys11]mastoparan to $\mathrm{G}_{\mathrm{o}}$. J Biol Chem 266:12655-12661

Higashijima T, Uzu S, Nakajima T, Ross EM (1988) Mastoparan, a peptide toxin from wasp venom, mimics receptors by activating GTPbinding regulatory proteins (G proteins). J Biol Chem 263:64916494

Higashijima T, Burnier J, Ross EM (1990) Regulation of $\mathrm{G}_{\mathrm{i}}$ and $\mathrm{G}_{\mathrm{o}}$ by mastoparan, related amphiphilic peptides, and hydrophobic amines. Mechanism and structural determinants of activity. J Biol Chem 265:14176-14186

Klinker JF, Hagelüken A, Grünbaum L, Heilmann I, Nürnberg B, Harhammer R, Offermanns S, Schwaner I, Ervens J, WenzelSeifert K, Müller T, Seifert R (1994) Mastoparan may activate GTP hydrolysis by $\mathrm{G}_{\mathrm{i}}$-proteins in HL-60 membranes indirectly through interaction with nucleoside diphosphate kinase. Biochem J 304:377-383

McNeil BD, Pundir P, Meeker S, Han L, Undem BJ, Kulka M, Dong X (2014) Identification of a mast-cell-specific receptor crucial for pseudo-allergic drug reactions. Nature. doi:10.1038/nature14022
Mousli M, Bronner C, Bueb JL, Tschihart E, Gies JP, Landry Y (1989) Activation of rat peritoneal mast cells by substance $\mathrm{P}$ and mastoparan. J Pharmacol Exp Ther 250:329-335

Mousli M, Bueb JL, Bronner C, Rouot B, Landry Y (1990a) G protein activation: a receptor-independent mode of action for cationic amphiphilic neuropeptides and venom peptides. Trends Pharmacol Sci 11:358-362

Mousli M, Bronner C, Landry Y, Bockaert J, Rouot B (1990b) Direct activation of GTP-binding regulatory proteins (G-proteins) by substance $P$ and compound 48/80. FEBS Lett 259:260-262

Norgauer J, Eberle M, Lemke HD, Aktories K (1992) Activation of human neutrophils by mastoparan. Reorganization of the cytoskeleton, formation of phosphatidylinositol 3,4,5-trisphosphate, secretion up-regulation of complement receptor type 3 and superoxide anion production are stimulated by mastoparan. Biochem J 282: 393-397

Offermanns S, Simon MI (1995) $\mathrm{G}_{\alpha 15}$ and $\mathrm{G}_{\alpha 16}$ couple to a wide variety of receptors to phospholipase C. J Biol Chem 270:15175-15180

Perianin A, Synderman R (1989) Mastoparan, a wasp venom peptide, identifies two discrete mechanisms for elevating cytosolic calcium and inositol trisphosphates in human polymorphonuclear leukocytes. J Immunol 143:1669-1673

Seifert R, Hagelüken A, Höer A, Höer D, Grünbaum L, Offermanns S, Schwaner I, Zingel V, Schunack W, Schultz G (1994) The $\mathrm{H}_{1}$ receptor agonist 2-(3-chlorophenyl)histamine activates $\mathrm{G}_{\mathrm{i}}$ proteins in $\mathrm{HL}$ 60 cells through a mechanism that is independent of known histamine receptor subtypes. Mol Pharmacol 45:578-586

Seifert R, Strasser A, Schneider EH, Neumann D, Dove S, Buschauer A (2013) Molecular and cellular analysis of human histamine receptor subtypes. Trends Pharmacol Sci 34:33-58

Sukumar M, Ross EM, Higashijima T (1997) A G $_{\mathrm{s}}$-selective analog of the receptor-mimetic peptide mastoparan binds to $\mathrm{G}_{\mathrm{s} \alpha}$ in a kinked helical conformation. Biochemistry 36:3632-3639

Tanaka T, Kohno T, Kinoshita S, Mukai H, Itoh H, Ohya M, Miyazawa T, Higashijima T, Wakamatsu K (1998) $\alpha$-Helix content of G protein $\alpha$ subunit is decreased upon activation by receptor mimetics. J Biol Chem 273:3247-3252

Wang H, Wang HS, Liu ZP (2011) Agents that induce pseudo-allergic reaction. Drug Disc Ther 5:211-219

Weingarten R, Ransnäs L, Mueller H, Sklar LA, Bokoch GM (1990) Mastoparan interacts with the carboxyl terminus of the $\alpha$ subunit of $\mathrm{G}_{\mathrm{i}}$. J Biol Chem 265:11044-11049 